\title{
Prawo autorskie w państwach Azji Środkowej
}

\section{Copyright law in the countries of Central Asia}

\section{Abstract}

The Berne Convention has not been ratified by the former Soviet Union. Far-reaching work to prepare the USSR for ratification of the Berne Convention was discontinued as a result of the break-up of this state. The Central Asian states acceded to the Berne Convention, independently of each other, after they had formally gained independence. The Commonwealth of Independent States to which the countries of Central Asia belong, has prepared rules for the creation of copyright laws for its members. The Eurasian Economic Union, which was established in 2015, is another international subject that influences the shape of copyright in the countries of Central Asia. The analysis of acts of copyright of the Central Asian states proves, firstly, that the laws of these states were modeled on the guidelines of the Commonwealth of Independent States, and secondly, it proves the high convergence of copyright laws. Differences, sometimes quite significant, reflect the cultural and social specificity of individual Central Asian republics.

Keywords: copyright law, Berne Convention, intellectual property, Central Asia, Commonwealth of Independent States, Eurasian Economic Union, fair use, protection of proprietary copyrights 


\section{Авторское право в странах Центральной Азии}

\section{Аннотачия}

СССР не ратифицировал Бернскую конвенцию, т.к. действия по подготовке всесоюзного и республиканского законодательства были прерваны в результате распада Советского Союза. Сторонами Бернской конвенции становились уже независимые государства Средней Азии по отдельности и в разное время. Созданное после распада СССР, Содружество Независимых Государств взяло на себя обязательства по интегрированию новых независимых республик в различных областях деятельности государства, в том числе и защите интеллектуальной собственности. Таким действием было принятие модельного закона об авторском праве и смежных правах, который послужил основой для законов стран Средней Азии. Евразийский Экономический Союз, созданный в 2015 году, является еще одной международной организацией, которая влияет на авторское право в странах Центральной Азии. Анализ актов авторского права центральноазиатских государств доказывает, во-первых, что законы этих государств были смоделированы по руководящим принципам Содружества Независимых Государств, а во-вторых, это свидетельствует о высокой конвергенции законов об авторском праве Различия, иногда весьма значимые, отражают культурную и социальную специфику отдельных центральноазиатских республик.

Ключевые слова: авторское право, Бернская конвенция, интеллектуальная собственность, Центральная Азия, СНГ, Евразийский Экономический Союз, свободное использование произведений, защита авторских иммущественных прав

$\mathrm{M}$ iędzynarodowe standardy ochrony własności intelektualnej zostały wyznaczone przez przyjętą w 1886 r. Konwencję berneńską o ochronie dzieł literackich i artystycznych ${ }^{1}$. Tekst konwencji podlegał na przestrzeni lat rewizjom i uzupełnieniom w: 1896 r. w Paryżu, 1908 r. w Berlinie, 1914 r. w Bernie, 1928 r. w Rzymie, 1948 r. w Brukseli, 1967 r. w Sztokhol-

${ }_{1}$ Polska ratyfikowała umowę w 1934 r. w tzw. redakcji rzymskiej z 2 czerwca 1928 r. Zob. ustawa z dnia 5 marca 1934 r. w sprawie ratyfikacji konwencji berneńskiej o ochronie dzieł literackich i artystycznych z dnia 9 września 1886 r., przejrzanej w Berlinie dnia 13 listopada 1908 r. i w Rzymie dnia 2 czerwca 1928 r., Dz.U. 1934, nr 27, poz. 213. Obecnie Rzeczpospolita jest związana Aktem paryskim Konwencji berneńskiej o ochronie dzieł literackich i artystycznych z 1971 r., ratyfikowanym dopiero 3 marca 1990 r. Zob. Dz.U.1990, nr 82, poz. 474. 
mie, 1971 r. w Paryżu. Standardy wyznaczone przez Konwencję berneńską winny być realizowane poprzez wprowadzenie do ustawodawstwa krajowego państwa ratyfikującego Konwencję odpowiednich zapisów, stosownych do kultury prawnej tego państwa. Ratyfikujący winien zapewnić przestrzeganie w swoim systemie prawnym standardów Konwencji. Zarówno realizacja ochrony własności intelektualnej, jak i mechanizmy jej egzekwowania zapewniane są przez państwo bez możliwości ingerencji zewnętrznej przez inne państwa lub podmioty ponadpaństwowe.

Konwencja berneńska była stopniowo ratyfikowana przez kolejne państwa, tak że praktycznie jej stronami stały się w zasadzie wszystkie. Przeciągającemu się procesowi ratyfikacji towarzyszyło oczekiwanie na powstanie ponadpaństwowego podmiotu, który mógłby zapewnić realizację zdefiniowanych standardów na jednakowym poziomie we wszystkich państwach członkowskich. Zadania tego podjęła się powstała w 1967 r. Światowa Organizacja Własności Intelektualnej (WIPO, która w 1974 r. stała się organizacją wyspecjalizowaną ONZ). WIPO uznaje za swój podstawowy cel zapewnianie współpracy administracyjnej w zakresie egzekwowania praw własności intelektualnej oraz praw autorskich. Ponadto stawia sobie za cel pogłębianie wiedzy z zakresu ochrony praw własności intelektualnej na arenie międzynarodowej. Do zadań WIPO należy przede wszystkim czuwanie nad przestrzeganiem umów międzynarodowych oraz przeciwdziałanie naruszeniom tych praw. W dniu 20 grudnia 1996 r. został sporządzony w Genewie Traktat Światowej Organizacji Własności Intelektualnej (WIPO) o prawie autorskim².

Państwa Azji Środkowej, jako republiki związkowe wchodzące w skład ZSRR, nie były stronami Konwencji berneńskiej, gdyż nie była ona ratyfikowana przez ZSRR. Dopiero w 1989 r. zgłoszono oficjalnie zamiar przyłączenia się ZSRR do Konwencji berneńskiej. Jednocześnie poczyniono odpowiednie kroki zmierzające do dostosowania przed 1991 r. ustawodawstwa ZSRR do standardów Konwencji berneńskiej. Towarzyszyły temu, co zrozumiałe, odpowiednie zmiany w prawie republik związkowych. Ówczesnym celem było dostosowanie ustawodawstwa związkowe-

2 Polska ratyfikowała Traktat WIPO w 2003 r., zob. ustawa z dnia 13 marca 2003 r. o ratyfikacji Traktatu WIPO o prawie autorskim, sporządzonego w Genewie dnia 1996 r., Dz.U. 2003, nr 80, poz. 715. 
go i republikańskiego do standardów Konwencji berneńskiej w redakcji Aktu rzymskiego. Analiza ustawodawstwa radzieckiego dowodzi, że przed rozpoczęciem harmonizacji prawa autorskiego nie było poważnych różnic między ustawodawstwem ZSRR a założeniami Konwencji berneńskiej (Goldman, 1990, s. 395-414). Radzieckie regulacje dotyczące dozwolonego użytku oraz licencji ustawowych nie przeczyły rozwiązaniom Konwencji berneńskiej. Nie było też rozbieżności w kwestiach autorstwa utworu, prawa do nienaruszalności utworu, jak również prawa do tantiem. Jedyną znaczącą różnicą było ograniczenie przez ustawodawstwo radzieckie praw autorów do określania warunków przeniesienia praw autorskich i udzielania licencji na korzystanie z utworu. Zaistniała natomiast konieczność rozszerzenia dwudziestopięcioletniego okresu ochrony praw autorskich majątkowych po śmierci twórcy. Niezbędne okazało się również usunięcie prawa do tłumaczenia oraz do publicznego odtworzenia utworu z listy licencji ustawowych (Закон СССР..., 1961) $)^{3}$.

$\mathrm{Z}$ powodu wydarzeń politycznych, które doprowadziły do rozpadu Związku Radzieckiego i powstania niepodległych republik na terenie Azji Środkowej, zamiar przystąpienia do Konwencji berneńskiej nie został przez ZSRR zrealizowany (Elst, 2005, s. 315) ${ }^{4}$. Przystąpienie do Konwencji berneńskiej przez niepodległe już państwa Azji Środkowej odbywało się na podstawie indywidualnych decyzji organów ustawodawczych. Do ratyfikacji doszło w różnym czasie. W Kazachstanie nastąpiło to w dniu 12 kwietnia 1999 r., w Kirgistanie - 8 lipca 1999 r., a w Tadżykistanie - 9 marca 2000 r. Uzbekistan i Turkmenistan przystąpiły do Konwencji berneńskiej znacząco później, odpowiednio - 19 kwietnia 2005 r. i 29 maja 2016 r. Roz-

${ }^{3}$ Ustawodawstwo radzieckie zezwalało na publiczne odtwarzanie rozpowszechnionych utworów bez zgody autora, po opłaceniu należnego twórcy wynagrodzenia oraz pod warunkiem wskazania imienia i nazwiska autora. Uzależnione to było także od tego, aby odbiorcy utworu mieli do niego dostęp nieodpłatnie. Zezwolenia nie wymagało utrwalenie w celu publicznego odtworzenia lub rozpowszechniania już rozpowszechnionych utworów z wyłączeniem wykorzystania w kinach, radiu i telewizji; wykorzystanie przez kompozytora utworów literackich w celu tworzenia utworów słowno-muzycznych, wykorzystywanie rozpowszechnionych dzieł sztuki, w tym także fotografii, w produkcji przemysłowej. W tym ostatnim przypadku wskazywanie imienia i nazwiska autora nie było wymagane.

${ }^{4}$ Należy nadmienić, że USA także przez dłuższy czas nie były stroną Konwencji berneńskiej, przystępując do niej dopiero w 1989 r. 
piętość czasowa między terminami ratyfikacji w tych państwach trudna jest do przekonywującego wytłumaczenia. Można zakładać, że wpływ na to miały względy polityki wewnętrznej.

Związek Radziecki był natomiast stroną Powszechnej konwencji o prawie autorskim opracowanej przez UNESCO w 1952 r. (UNESCO, 2002). Mimo to ZSRR przede wszystkim realizował ochronę w dziedzinie własności intelektualnej w oparciu o zawierane zarówno wcześniej, jak i w późniejszych latach, umowy dwustronne m.in. z NRD (1973 r.), Polską (1974 r.), Czechosłowacją (1975 r.), Bułgarią (1975 r.), Austrią (1981), Kubą (1986 r.). Umowy dwustronne często wykraczały poza zakres regulacji Powszechnej Konwencji. W 1988 r. ZSRR przystąpił do Konwencji brukselskiej o rozpowszechnianiu drogą satelitarną sygnałów przenoszących program z 1974 r. (Date of accession..., 1991).

Po rozpadzie ZSRR rola podmiotu harmonizującego standardy ochrony własności intelektualnej oraz inicjującego działania na ponadpaństwowym poziomie, zmierzające do ochrony szeroko rozumianej własności intelektualnej znalazła się w gestii Wspólnoty Niepodległych Państw. We wrześniu 1993 r. zostało podpisane Porozumienie o współpracy w dziedzinie ochrony prawa autorskiego i praw pokrewnych (Соглашение О...). Członkowie WNP zobowiązali się do przestrzegania standardów określonych jeszcze przez ustawodawstwo ZSRR w dziedzinie prawa autorskiego, co potwierdziły dokumenty wewnętrzne, regulujące zasady odpowiedniego stosowania prawa ZSRR, do czasu przyjęcia ustaw krajowych. Pamiętać należy, że jeszcze w 1991 r. wydany został Dekret Rady Najwyższej ZSRR o wprowadzeniu zasad cywilnego ustawodawstwa (Постановление Верховного Совета..., 1991). W tekście Zasad znalazł się rozdział zatytułowany „Prawo Autorskie”. Zasady utraciły moc w 1994 r., co doprowadziło do powstania pewnej luki prawnej, gdyż niektóre powstałe po rozpadzie ZSRR państwa, m.in. Tadżykistan, nie zdążyły uchwalić ustaw krajowych i pozostały bez jakichkolwiek regulacji prawnych w dziedzinie prawa autorskiego. Rozwiązaniem dla powstałej sytuacji stało się właśnie Porozumienie z 1993 r., które podpisało dziesięć państw (wśród nich Kazachstan, Kirgistan, Tadżykistan, Turkmenistan i Uzbekistan). W czerwcu 1995 r. w Ałma-Acie odbyło się regionalne seminarium w sprawie praw autorskich dla Azji Środkowej. Kolejne akty międzynarodowe, podejmowane przez WNP, to rezolucja Zgromadzenia Międzyparlamentarnego Państw 
Członkowskich Wspólnoty Niepodległych Państw z 18 listopada 2005 r. w sprawie nowej redakcji wzorcowej ustawy o prawach autorskich i prawach pokrewnych (Постановление Межпарламентской Ассамблеи..., 2006) oraz umowa o współpracy w sprawie organizacji międzystanowej wymiany informacji i tworzenia krajowych baz danych dotyczących praw autorskich i pokrewnych (Соглашение от 20 ноября 2009 года...).

Wielorakie inicjatywy integracyjne, dotyczące zarówno gospodarki, obronności, bezpieczeństwa, obejmujące państwa byłego ZSRR skutkowały powstawaniem szeregu jednostek ponadpaństwowych. Nie doprowadziły jednak do trwalszej współpracy państw, lecz wręcz przeciwnie, powodowały coraz mniejsze ich zainteresowanie integracją obszaru całego b. ZSRR. Efektem stały się inicjatywy indywidualnych i regionalnych integracji o mniejszym zakresie terytorialnym, obejmujące np. Azję Środkową lub Kaukaz. Nie wszystkie z nich zostały zrealizowane z powodzeniem, pozostając na etapie uroczystego podpisania dokumentów o intencjach stron. Państwa nadbałtyckie zakończyły sukcesem dążenia do integracji z państwami Europy Zachodniej, przystępując w 2004 r. do Unii Europejskiej.

Federacja Rosyjska, jako główny animator procesów integracyjnych obejmujących obszar byłego ZSRR, stała się inicjatorem kolejnego etapu integracji mającego skupić państwa $\mathrm{z}$ nią graniczące. Efektem tych działań stała się funkcjonująca oficjalnie od 1 stycznia 2015 r. Euroazjatycka Unia Gospodarcza (dalej: EaUG), skupiająca obecnie poza Rosją: Białoruś, Kazachstan, Armenię i Uzbekistan. Nie udało się jednak pozyskać do tej wspólnoty Ukrainy. Działania EaUG koncentrują się przede wszystkim na integracji gospodarczej. Dotykają jednak w dużej mierze także ochrony własności intelektualnej. Dowodzi tego przyjęcie przez Zgromadzenie Międzyparlamentarne Eurazjatyckiej Wspólnoty Gospodarczej rezolucji z 16 maja 2012 r. Nr 14-16 o zaleceniach w sprawie harmonizacji ustawodawstwa państw członkowskich EaUG w zakresie praw autorskich i pokrewnych (na podstawie porównawczej analizy prawnej prawodawstwa krajowego) (Постановление Межпарламентской Ассамблеи..., 2006).

Akty normatywne państw Azji Środkowej odnoszące się do prawa autorskiego powstawały na różnych etapach tworzenia państwowości. Kazachstan uchwalił ustawę o prawie autorskim i prawach pokrewnych 10 czerwca 1996 r. (Закон Республики Казахстан..., 1996), która z licznymi zmianami obowiązuje po dzień dzisiejszy. W Uzbekistanie pierwsza usta- 
wa o prawie autorskim i prawach pokrewnych została uchwalona 30 sierpnia 1996 r. (Закон Республики Узбекистан N 272-I..., 1996). Zastąpiła ją nowa ustawa z 20 lipca 2006 r. (Закон Республики Узбекистан..., 2006). W Kirgistanie ustawa o prawie autorskim i prawach pokrewnych została uchwalona 14 stycznia 1998 r. (Закон Кыргызской Республики..., 1998). W Tadżykistanie takowa ustawa powstała 13 listopada 1998 r. (Закон Республики Таджикистан..., 1998). Najpóźniej, bo dopiero w 2012 r. ustawę o prawie autorskim i prawach pokrewnych uchwalono w Turkmenistanie (Закон Туркменистана..., 2012). Wcześniej zagadnienia prawa autorskiego w tej republice regulowała część czwarta kodeksu cywilnego, która z chwilą przyjęcia ustawy w tej dziedzinie, zmieniła nazwę na prawo własności intelektualnej (Закон Туркменистана № 256-IV..., 2012).

Przechodząc do bardziej szczegółowej oceny najważniejszych założeń prawa autorskiego w państwach Azji Środkowej, należy raz jeszcze podkreślić, że punktem wyjścia dla obowiązujących ustaw był wzór zaproponowany przez WNP państwom członkowskim. Specyfika sytuacji wewnętrznej każdego z państw danego obszaru spowodowała, że w ustawach znajdują się zarówno identycznie brzmiące przepisy, jak również uzupełnienia i zmiany charakterystyczne tylko dla tej republiki. Ustawy zostały poddane analizie pod kątem kilku kryteriów: określenia przedmiotu ochrony oraz warunków objęcia go ochroną, podmiotu prawa autorskiego, osobistych i majątkowych praw autorskich - w odniesieniu do tych ostatnich - granic, czasu trwania oraz instrumentów ochrony. Każda z ustaw posiada także regulacje wykraczające poza wskazane kryteria, ale ramy niniejszego opracowania nie pozwalają na przytoczenie wyczerpującej analizy każdej z pięciu ustaw.

Przedmiot ochrony zdefiniowany został we wszystkich pięciu ustawach w zasadzie identycznie. Wskazano że są nim utwory naukowe, literackie i sztuka, będące wynikiem działalności twórczej, niezależnie od przeznaczenia, wartości i treści, a także sposobu i formy ich wyrazu. Sposób dookreślenia przedmiotu ochrony różni się jednak w zależności od koncepcji przyjętej przez konkretnego ustawodawcę. W art. 2 Konwencji berneńskiej wskazano, że wyrazy „dzieła literackie i artystyczne” obejmują wszelkie utwory literackie, naukowe i artystyczne, bez względu na sposób lub formę ich wyrażenia, a więc: książki, broszury i inne pisma; teksty odczytów, przemówień, kazań i innych dzieł tego samego rodzaju. Ponadto wskaza- 
no tu: dzieła dramatyczne lub dramatyczno-muzyczne; dzieła choreograficzne i pantomimy, których układ sceniczny został ustalony na piśmie lub w inny sposób. Dalej wymieniono: utwory muzyczne ze słowami lub bez słów; utwory rysunkowe, malarskie, architektoniczne, rzeźby, utwory rytownicze i litograficzne; ilustracje, mapy geograficzne; plany, szkice i wyroby plastyczne, dotyczące geografii, topografii, architektury. Wykaz ten uzupełniono o programy komputerowe. Mimo że treść listy zdaje się wskazywać na jej enumeratywny charakter, to ustawy omawianych państw Azji Środkowej, przejmując wspomniane zestawienie, kończy je punktem „i inne utwory”. Wyjątkiem jest ustawa Turkmenistanu, która jako przedmioty prawa autorskiego wskazuje: utwory literackie (książki, broszury, artykuły, programy komputerowe, bazy danych itd.); dramatyczne i muzyczno-dramatyczne, choreograficzne i inne utwory scenariuszowe; muzyczne utwory z tekstem lub bez tekstu; utwory audiowizualne (filmowe, telewizyjne, wideofilmy, slajdy i inne utwory audiowizualne); rzeźby, obrazy, grafiki, litografie i inne dzieła sztuki; utwory dekoracyjne, użytkowe, monumentalne, architektoniczne, urbanistyczne, architektury krajobrazu; fotografie i utwory uzyskane technikami analogicznymi fotografii; mapy, plany, szkice, ilustracje i trójwymiarowe prace związane z geografią, topografią i innymi naukami. Przedstawiona w art. 6 ustawy Turkmenistanu lista ma charakter zamknięty, ściśle enumeratywny.

Szczególne miejsce w określeniu przedmiotu ochrony zajmuje twórczość tłumaczy, gdyż we wszystkich pięciu ustawach wymieniono te utwory jako regulacje dotyczące utworów zależnych. W ustawie turkmeńskiej tłumaczom poświęcono art. 11, w którym zagwarantowano prawa wyłączne tłumacza do stworzonego tłumaczenia, pod warunkiem przestrzegania praw autora utworu pierwotnego. Podkreślono iż prawa te nie pozwalają na ograniczanie innym twórcom tworzenie utworów zależnych i tłumaczeń w oparciu o ten sam utwór pierwotny. W ustawie uzbeckiej zaznaczono dodatkowo, że twórca utworu nie ma możliwości uczestniczenia w prawach do tłumaczenia ani decydowania o sposobie eksploatacji tłumaczenia po wyrażeniu zgody na jego publiczne udostępnienie. 


\section{Kazachstan}

Kazachska ustawa wskazuje wyraźnie w treści art. 8, że utwór zostaje objęty ochroną prawnoautorską z chwilą jego powstania, bez potrzeby spełnienia jakichkolwiek dodatkowych warunków. Ustawowe domniemanie autorstwa zakłada, że autorem jest osoba wskazana w tym charakterze na egzemplarzu utworu. Zaznaczono że zamieszczenie na egzemplarzu utworu noty copyrightowej (c) ma charakter jedynie deklaratoryjny. Zadaniem jej jest poinformowanie odbiorcy o autorstwie i udziałach współautorów. Fakt zamieszczenia noty copyrightowej lub jej brak nie rodzi żadnych konsekwencji prawnych. Kolejnym przywilejem mającym służyć autorom jest możliwość zarejestrowania utworu jako przedmiotu objętego ochroną prawnoautorską w rejestrze państwowym ${ }^{5}$.

Prawa autorskie do utworów audiowizualnych w kazachskiej ustawie prawnoautorskiej przyznano: autorowi scenariusza, twórcy utworu muzycznego lub słowno-muzycznego powstałego celem jego włączenia do utworu audiowizualnego, reżyserowi, operatorowi, twórcy kostiumów i dekoracji. Ponadto autorzy utworów przetworzonych lub włączonego do utworu audiowizualnego mają, podobnie jak twórcy utworzonych specjalnie na potrzeby tego utworu, status współautorów utworu audiowizualnego. Do autorskich praw osobistych ustawodawca kazachski zaliczył: prawo do autorstwa, pseudonimu i poszanowania woli anonimowego rozpowszechniania utworu, prawo żądania wskazywania autora na egzemplarzach utworu oraz przy każdym wykorzystaniu utworu, prawo nienaruszalności utworu jego formy, treści i tytułu. Ponadto wskazał tu prawo do decydowania o opublikowaniu utworu, jak również prawo do wycofania utworu z publicznego dostępu, jednak z wyjątkiem utworów pracowniczych. Wyraźnie wskazano,

5 Zgodnie z art. 9-1 ustawy kazachskiej rejestracja autorstwa utworu odbywa się $\mathrm{w}$ trybie postępowania administracyjnego i nie powodują silniejszej ochrony, a jedynie służy urzędowym potwierdzeniem autorstwa. Nie wyklucza to możliwości obalenia tego autorstwa w trybie postępowania sądowego. Ponieważ warunkiem rejestracji jest przedstawienie organowi rejestracyjnemu egzemplarza utworu, to prawo rejestracji autorstwa wiąże się z utrwaleniem lub publikacją utworu. Nadmienić należy, że utwór jest objęty ochroną z chwilą powstania. W treści art. 9-1 przewidziano siedem specyficznych kompletów wymaganych dokumentów, które są niezbędne do zarejestrowania poszczególnych kategorii utworów. 
że autorskie prawa osobiste są niezbywalne i przynależą twórcy niezależnie od praw autorskich majątkowych.

Autorskie prawa majątkowe kazachska ustawa pojmuje jako prawo: odtwarzania, rozpowszechniania, importu egzemplarzy, pokazu publicznego, wykonania publicznego, rozpowszechniania, nadawania, reemisji, tłumaczenia, przetwarzania. Rząd Kazachstanu określa minimalne stawki wynagrodzenia za korzystanie z utworów objętych ochroną prawnoautorską (Постановление Правительства..., 2004). Uregulowano droit de suite jako prawo do $5 \%$ od ceny sprzedaży egzemplarzy utworu plastycznego dokonywanej przez podmiot profesjonalny ${ }^{6}$. Prawo to jest niezbywalne za życia twórcy, a po jego śmierci przechodzi wyłącznie na spadkobierców ustawowych lub testamentowych w okresie ochrony autorskich praw majątkowych.

Przyznany przez ustawodawcę dozwolony użytek w postaci prawa do odtworzenia dla użytku osobistego i niekomercyjnego pojedynczego egzemplarza rozpowszechnionego utworu nie uwzględnia możliwości odtworzenia utworów architektonicznych w postaci budowli, powielenia baz danych w całości lub części, powielania programów komputerowych, a co najważniejsze - reprodukcji lub reprografii notacji muzycznych oraz wydawnictw książkowych w całości. W ustawie ponadto przewidziano dozwolony użytek w postaci: cytowania w celach naukowych, badawczych, polemicznych, krytycznych i informacyjnych, a także korzystania z utworów w celach nauczania, przedruku prasowego, informowania o bieżących wydarzeniach, w sytuacjach uzasadnionych niepełnosprawnością użytkowników, wreszcie zapisano użytek bibliotek i archiwów. Nie wymaga zgody twórcy ani wniesienia opłaty za korzystanie z utworów znajdujących się na stałe w miejscu publicznie dostępnym. Podobnie możliwe jest korzystanie z utworów dla celów oficjalnych lub religijnych uroczystości, jak również wszelkich ceremonii pogrzebowych. Wśród licencji ustawowych znalazło się korzystanie z utworów na potrzeby postępowania sądowego lub administracyjnego, a także dozwolony użytek osobisty ${ }^{7}$.

${ }^{6}$ Zgodnie z art. 17 ustawy prawnoautorskiej Kazachstanu prawo do droit de suite zaczyna obowiązywać od pierwszego przejścia prawa własności utworu plastycznego zarówno odpłatnie, jak i nieodpłatnie.

7 Dozwolony użytek osobisty został sformułowany w taki sposób, że osoba prywatna, korzystająca z niego w celach osobistych, niezawodowych i niezarobkowych nie musi 
Autorskie prawa majątkowe są chronione przez okres 70 lat po śmierci twórcy lub ostatniego ze współtwórców. Utwory anonimowe lub rozpowszechnione pod pseudonimem są chronione przez 70 lat od dnia opublikowania, chyba że do dnia upływu tego terminu autor ujawni swoje imię i nazwisko. Na uwagę zasługuje regulacja dotycząca utworów, które zostały po raz pierwszy udostępnione po śmierci twórcy. Są one objęte ochroną praw autorskich majątkowych przez 70 lat od chwili opublikowania, jednak pod warunkiem, że ich pierwsze udostępnienie nastąpiło nie później niż 30 lat po śmierci twórcy. Tym samym może dojść do sytuacji, gdy niektóre utwory twórcy będą objęte ochroną nawet przez 100 lat po śmierci twórcy, np. wspomnienia autora, który zastrzegł możliwość publikacji dopiero w konkretnym roku po śmierci, co zresztą miało nieraz miejsce w przypadku znanych osób.

Ustawa kazachska wprowadza pojęcie domeny publicznej, stwierdzając w art. 29 że przechodzą do niej wszystkie utwory po upływie okresu ochrony autorskich praw majątkowych. Poza tym stwierdzeniem nie podjęto żadnych dalszych kroków celem uporządkowania domeny publicznej np. w postaci rejestru dzieł, które takowy status uzyskały. W sposób bardzo szeroki i wyczerpujący ustawa odnosi się do zasad i formy zawierania umów prawnoautorskich. Wymieniono w niej nie tylko elementy konieczne dla ważności takiej umowy, lecz także szereg domniemań prawnych i okoliczności, które nie mogą zostać uregulowane na drodze umowy pozostając jako ius cogens w formie ustalonej przez ustawę.

Ochrona praw autorskich może być realizowana poprzez: uznanie praw, domaganie się przywrócenia stanu sprzed naruszenia prawa, zaprzestanie naruszania lub działań stwarzających zagrożenie naruszenia, naprawienie szkody, w tym utraconych korzyści, wreszcie wydanie dochodu uzyskanego przez naruszającego w związku z naruszeniem praw autorskich lub

uzyskiwać zgody twórcy na korzystanie z utworu. Twórcy należy się jednak za takie użytkowanie wynagrodzenie, odmiennie niż w polskiej ustawie. Wynagrodzenie to nie jest jednak uiszczane przez użytkownika za rzeczywisty fakt korzystania, lecz pośrednio poprzez opłatę dodawaną do ceny czystych nośników i sprzętu umożliwiającego korzystanie $z$ utworów lub ich powielanie. Tym samym konstrukcja opłat reprograficznych, znana na polskim gruncie prawnych $\mathrm{z}$ art. 20 ustawy o prawie autorskimi i prawach pokrewnych (Dz.U. 2018, poz. 1191) została „wyjęta” z kategorii godziwej rekompensaty za korzystanie i „ujęta” w kategorii wynagrodzenia należnego twórcy za korzystanie z jego twórczości. 
pokrewnych oraz wypłatę kompensaty w wysokości od 100 do 15 tys. minimalnych wynagrodzeń. W ustawie przewidziano również regulacje dotyczące praw pokrewnych oraz działalności organizacji zbiorowego zarządzania prawami autorskimi, których analiza przekracza ramy niniejszego opracowania.

\section{Uzbekistan}

Do specyficznych cech wyróżniających uzbecką ustawę prawnoautorską zaliczyć należy m.in. dość obszerną regulację dotyczącą praw do projektów oficjalnych dokumentów, symboli i znaków. Zaznaczono że prawa do nich należą się twórcom i są oni uprawnieni do publikowania takich projektów i wskazywania swoich imion i nazwisk, jeżeli nie zostało to zakazane przez organ zlecający stworzenie takowych projektów. Jednocześnie wspomniane projekty mogą być wykorzystywane do sporządzenia oficjalnej dokumentacji bez zgody twórcy, jeżeli zostały one przekazane organowi zamawiającemu. Organ zamawiający ma również ustawowe prawo wnoszenia poprawek do projektów na etapie ich tworzenia. Po zatwierdzeniu dokument, symbol lub znak mogą być wykorzystywane bez wskazania imienia i nazwiska twórcy. Objęcie każdego utworu ochroną prawnoautorską następuje z mocy ustawy i nie wymaga spełnienia żadnych wymogów. Funkcjonuje domniemanie autorstwa osoby wskazanej na egzemplarzu utworu. Zawarowano możliwość informowania o swoich prawach autorskich za pośrednictwem znaku @, podkreślając że nie rodzi to żadnych dodatkowych uprawnień ani większej ochrony. Nie przewidziano utworzenia żadnego rejestru praw autorskich. Do grona twórców utworów audiowizualnych zaliczono: reżysera, autora scenariusza, twórcę utworu muzycznego lub słowno-muzycznego powstałego celem jego włączenia do utworu audiowizualnego, operatora, twórcę kostiumów i dekoracji. Zapisano ponadto prawo twórcy utworu muzycznego lub słowno-muzycznego powstałego celem jego włączenia do utworu audiowizualnego do otrzymania wynagrodzenia za każde publiczne odtworzenie utworu audiowizualnego. W odrębnym artykule określono prawa do wywiadu jako do utworu współautorskiego tworzonego przez udzielającego wywiadu oraz przepro- 
wadzającego wywiad - co wydaje się ewenementem z punktu widzenia rozwiązań europejskich.

Pewnym novum, którego mogłyby pozazdrościć państwa $\mathrm{UE}^{8}$, jest prawo podmiotu organizującego powstanie utworu. Zaliczono do nich m.in. organizatorów produkcji utworów audiowizualnych, wydawców encyklopedii, producentów. Nie przyznaje im się statusu autorów, co wyraźnie zaznaczono w ustawie, jednak nabywają wyłączne prawo do korzystania z tych utworów oraz domagania się wskazywania swojej nazwy lub imienia i nazwiska.

Autorskie prawa osobiste, określone jako niemajątkowe, składają się z prawa do: autorstwa, domagania się wskazania osoby twórcy, decydowania o publicznym udostępnieniu utworu oraz wycofania utworu z obrotu publicznego, wreszcie ochrony utworu, w tym jego nazwy, formy i treści. Prawo do wycofania utworu nie obejmuje utworów pracowniczych. Wyraźnie zakazano opatrywania utworu ilustracjami, wstępem, zakończeniem, słowem wprowadzającym, komentarzami lub jakimikolwiek wyjaśnieniami - bez zgody twórcy. Stwierdzono że autorskie prawa osobiste są niezbywalne, a jakiekolwiek umowy lub porozumienia $\mathrm{z}$ twórcą albo jego oświadczenia zakładające przeniesienie autorskich praw osobistych lub ich zrzeczenie się są nieważne.

Autorskie prawa majątkowe składają się z prawa: odtwarzania, rozpowszechniania, publikowania, najmu, importu, emisji i reemisji, przetworzenia, publicznego udostępniania, publicznego wykonania, nadawania, tłumaczenia oraz prawa do wynagrodzenia. Wyraźnie wyróżniono prawa tłumaczy jako autonomiczne prawa do utworu, bez udziału w nich twórcy utworu pierwotnego. Autorskie prawo majątkowe do utworu architektonicznego, urbanistycznego oraz krajobrazowego obejmuje swoim zasięgiem także prawo do realizacji takowego projektu. Uwzględniono jednocześnie prawo domagania się przez twórcę, aby zamawiający dopuścił go do udziału w realizacji i budowie obiektów powstających na podstawie stworzonej

${ }^{8}$ Szerzej o problemach prawnych dotyczących wydawców prasy oraz działaniach na rzecz ustanowienia praw pokrewnych dla wydawców: Kakareko, K. (2017), Prawa pokrewne wydawców czasopism naukowych, Acta Iuris Stetinensis (Roczniki Prawnicze), Nr 2(18), 115-134; Sobczak, J., Kakareko, K. (2017), Czy istnieje potrzeba wyodrębnienia praw pokrewnych wydawców?. W: J. Mianowski (red.), Stowarzyszenie prasy lokalnej. Od 25 lat buduje społeczeństwo obywatelskie, Poznań, 34-43. 
przez twórcę dokumentacji. Nie sposób dociec czy pod tym udziałem należy rozumieć coś więcej niż prawo twórcy do nadzoru nad realizowanym obiektem. Twórcy utworów audiowizualnych oraz programów komputerowych mają - w myśl ustawy - wyłączne prawo udzielania zgody na najem oryginału lub egzemplarzy utworu. Przy tym nie dotyczy to przypadków gdy najem utworu audiowizualnego nie prowadzi do odtworzenia powodującego znaczącą szkodę dla praw wyłącznych oraz sytuacji gdy program komputerowy nie jest przedmiotem najmu, a jedynie instrumentem pomocniczym przy najmie innego utworu.

W odniesieniu do utworów plastycznych przewidziano droit de suite w przypadku publicznej sprzedaży jego egzemplarzy (aukcja, galeria, sklep etc.) pod warunkiem, że cena sprzedaży przewyższy cenę poprzedniej sprzedaży o co najmniej 25 proc. Wówczas twórca lub jego spadkobiercy uzyskują prawo do kwoty stanowiącej 5 proc. od ceny sprzedaży. Ponadto twórca utworu plastycznego ma zagwarantowane prawo dostępu do utworu celem jego odtworzenia, a właściciel/posiadacz utworu plastycznego nie może się temu sprzeciwić. Nie uprawnia to jednak twórcy do żądania dostarczenia jemu utworu przez jego obecnego właściciela bądź posiadacza.

Autorskie prawa majątkowe zostały ograniczone szeregiem przypadków dozwolonego użytku. Prawo do użytku osobistego zezwala na korzystanie, bez potrzeby uzyskania zgody oraz bezpłatnie, z utworów, oprócz, do celów osobistych i niezarobkowych. Wyjątek stanowią programy komputerowe oraz przypadki odtworzenia: utworów architektonicznych w postaci budynków, baz danych i ich części, reprografii notacji muzycznych oraz publikacji książkowych w całości. Opłaty reprograficzne przewidziano jako zapłatę za korzystanie w ramach dozwolonego użytku osobistego $\mathrm{z}$ utworów audiowizualnych i fonogramów.

Zagwarantowano prawo cytatu do celów naukowych, badawczych, polemicznych, krytycznych oraz niezwiązanych z reklamą celów informacyjnych, prawo przedruku prasowego, prawo korzystania z utworów do celów nauczania, w tym także w materiałach dydaktycznych, prawo korzystania z utworów w sposób odpowiadający niepełnosprawności użytkownika, wreszcie prawo użytku bibliotecznego i archiwalnego. Dozwolonym użytkiem objęto utwory wystawione na stałe w miejscach publicznie dostępnych, wyłączając przypadki gdy prezentacja utworu jest przedmiotem nadania, emisji lub reemisji, a także gdy wykorzystywana jest do celów ko- 
mercyjnych. Nie wymaga zgody twórcy i zapłaty korzystanie z utworów (jedynie!!!) muzycznych podczas ceremonii oficjalnych, religijnych i pogrzebowych. Ponadto licencja ustawowa obejmuje korzystanie z utworów do celów przeprowadzenia przesłuchań, postępowania przygotowawczego, administracyjnego oraz sądowego.

Jako niezmiernie ciekawe jawią się regulacje dotyczące utworu pracowniczego. Autorskie prawa osobiste do utworu powstałego w wyniku wykonywania obowiązków służbowych lub poleceń służbowych należą do twórcy. Wyłączne prawa do korzystania z utworu pracowniczego należą do pracodawcy, chyba że umowa stanowi inaczej. Wysokość wynagrodzenia za każde pole eksploatacji utworu pracowniczego oraz tryb jego wypłacania winny być uregulowane w umowie między pracownikiem i pracodawcą. Z upływem lat dziesięciu od opublikowania utworu pracowniczego, a za zgodą pracodawcy wcześniej, twórca nabywa w pełnym wymiarze prawo korzystania z utworu i otrzymywania wynagrodzenia, niezależenie od postanowień umowy zawartej z pracodawcą. Korzystanie przez twórcę $\mathrm{z}$ utworu pracowniczego niezwiązane $\mathrm{z}$ celem jego powstania nie jest ograniczone. Pracodawca ma prawo, w przypadku korzystania $\mathrm{z}$ utworu pracowniczego, żądać wskazania swojej nazwy. Regulacje dotyczące utworów pracowniczych nie dotyczą encyklopedii i słowników encyklopedycznych, naukowych periodyków i serii wydawniczych, prasy i innych wydawnictw periodycznych.

Okres ochrony autorskiego prawa majątkowego trwa 50 lat po śmierci twórcy lub ostatniego ze współtwórców. Utwory anonimowe lub opublikowane pod pseudonimem podlegają ochronie przez okres 50 lat od dnia opublikowania, chyba że w tym okresie ujawni się ich autor. Ochrona utworów opublikowanych po śmierci twórcy trwa przez 50 lat od dnia ich opublikowania, przy czym nie wprowadzono żadnych ograniczeń dotyczących terminu publikacji po śmierci twórcy.

Przejście do domeny publicznej następuje w wyniku upływu terminu ochrony autorskich praw majątkowych. Podkreślono że utwory, które nie zostały objęte ochroną prawnoautorską na terenie Uzbekistanu, uznaje się za znajdujące się w domenie publicznej. Korzystanie z takich utworów nie wymaga opłaty wynagrodzenia, lecz konieczne jest przestrzeganie autorskich praw osobistych. W sześciu obszernych artykułach (37-42) uregulowano bardzo szczegółowo zasady zawierania umów prawnoautorskich. 
Ochrona autorskich praw majątkowych realizowana jest przez: uznanie praw, domaganie się przywrócenia stanu sprzed naruszenia prawa, zaprzestanie naruszania lub działań stwarzających zagrożenie naruszenia, naprawienia szkody, w tym utraconych korzyści oraz wypłaty kompensaty w miejsce naprawienia szkody, wypłacanej nienależnie od faktu powstania szkody. W tym ostatnim przypadku zależne to jest od charakteru naruszenia i stopnia winy naruszającego. Podkreślono że straty poniesione przez osoby trzecie w wyniku podjęcia działań niezbędnych dla zapobieżenia naruszaniu lub jego zaprzestaniu oraz straty podmiotu, które takowe działania podejmował - ponosi podmiot naruszający. Ponadto ustawa zawiera regulacje dotyczące praw pokrewnych i organizacji zbiorowego zarządzania prawami autorskimi.

\section{Kirgistan}

Osobliwością prawa autorskiego Kirgistanu jest zaliczenie twórczości ludowej do dzieł niechronionych ustawą obok oficjalnych dokumentów, znaków i symboli państwowych, prostych informacji prasowych o bieżących wydarzeniach. Do grona tego zaliczono ponadto wyniki uzyskane przy wykorzystaniu środków technicznych i przeznaczone do wykorzystania, bez udziału twórczości człowieka (art. 8). Przewidziano iż twórca może posłużyć się notą copyrightową (C) umieszczając ją na egzemplarzach utworu, jednak fakt ten nie miał wywoływać żadnych innych skutków prawnych poza informacją do kogo należały autorskie prawa majątkowe w chwili publikacji. Umożliwiono także dokonanie rejestracji utworu w rejestrze prowadzonym przez Urząd Patentowy Kirgistanu, wraz z informacją o jego twórcy i osobie której przysługują autorskie prawa majątkowe. Do twórców utworów audiowizualnych zaliczono: autora scenariusza, twórcę utworu muzycznego lub słowno-muzycznego stworzonego do wykorzystania w utworze audiowizualnym, reżysera oraz dyrektora artystycznego.

Utwory pracownicze, na zasadach wyłącznego prawa korzystania z utworu, należą - w myśl kirgiskiej ustawy - do pracodawcy. Autorskie prawa osobiste do utworu pracowniczego należą do twórcy, przy tym pracodawca ma prawo do wskazania swojej nazwy przy każdym wykorzystaniu utworu pracowniczego. Po upływie dziesięciu lat od powstania utworu, 
za zgodą pracodawcy wcześniej, prawo twórcy do korzystania z utworu pracowniczego oraz prawo do wynagrodzenia przysługują w pełni twórcy, bez względu na treść postanowień umowy o pracę.

$\mathrm{Na}$ autorskie prawa osobiste składają się prawo do: autorstwa, oznaczenia utworu swoim nazwiskiem lub pseudonimem albo udostępniania go anonimowo, decydowanie o pierwszym udostępnieniu utworu publiczności, w tym także o wycofaniu utworu oraz nienaruszalności utworu, rozumiane jako prawo do ochrony utworu i jego tytułu.

Do autorskich praw majątkowych ustawodawca zaliczył: prawo do odtwarzania, rozpowszechniania, importu, publicznego odtwarzania, publicznego wykonania, nadawania i reemisji, prawo do tłumaczenia, opracowania i opublikowania. Zaznaczono że wyłączne prawo do korzystania $\mathrm{z}$ architektonicznego, urbanistycznego i krajobrazowego utworu zakłada również praktycznej ich realizacji. Twórcy takich projektów mają zagwarantowane przez ustawę prawo domagania się od zamawiającego prawa uczestniczenia w realizacji swojego projektu na etapach przygotowywania dokumentacji i budowy, co sprowadza się do wykonywania nadzoru nad sposobem korzystania $\mathrm{z}$ utworu.

Okres ochrony autorskiego prawa majątkowego przewidziano na 50 lat po śmierci twórcy lub ostatniego ze współtwórców. Utwór anonimowy objęty jest ochroną przez 50 lat po roku jego rozpowszechnienia. Jednak utwory rozpowszechnione w ciągu 50 lat po śmierci twórcy podlegają ochronie przez okres 50 lat licząc od 1 stycznia roku następnego po roku rozpowszechnienia. Zaznaczono wyraźnie, że autorstwo, imię twórcy oraz nienaruszalność utworu - a więc autorskie prawa osobiste - są chronione bezterminowo.

Twórcy utworów plastycznych przyznano prawo domagania się od ich właścicieli możliwości realizacji prawa odtworzenia utworu poprzez zapewnienie dostępu do tego utworu. Nie łączy się to z możliwością domagania się od właściciela utworu plastycznego dostarczenia go do twórcy. Każda publiczna sprzedaż utworu plastycznego przez galerię, salon artystyczny, sklep etc. bądź w wyniku aukcji, uprawnia twórcę oraz jego spadkobierców (ustawowych lub testamentowych) do otrzymania 5 proc. od ceny sprzedaży.

Do dozwolonego użytku zaliczono: prawo cytatu, rozumiane jako korzystanie do celów naukowych, badawczych, polemiki, krytyki i informowania; prawo przedruku prasowego; prawo użytku dla bibliotek i archiwów. 
Za dozwolony użytek uznano: publiczne wykonywanie utworów podczas ceremonii oficjalnych, religijnych i pogrzebowych; korzystanie z utworów do celów postępowań sądowych i administracyjnych; prawo tymczasowego przechowywania utworów emitowanych przez nadawców; wreszcie prywatny niekomercyjny użytek osobisty.

W ustawie posłużono się pojęciem domeny publicznej, rozumianej jako ogół utworów, wobec których wygasły autorskie prawa majątkowe oraz utworów, które nigdy nie uzyskały ochrony prawnoautorskiej na terenie Kirgistanu. Zagwarantowano prawo swobodnego korzystania z utworów zaliczanych do domeny publicznej przez dowolne kategorie podmiotów bez wypłaty wynagrodzenia, pod warunkiem poszanowania autorskich praw osobistych. Na rząd Kirgistanu nałożono obowiązek określenia wysokości kwot przekazywanych do Państwowego Funduszu Własności Intelektualnej z tytułu korzystania $\mathrm{z}$ utworów zaliczanych do domeny publicznej (art. 28 ust. 3).

W ustawie bardzo szczegółowo opisano zasady przejścia autorskich praw majątkowych na podstawie umowy oraz $\mathrm{w}$ drodze dziedziczenia (art. 29-33). Wskazane zostały minimalne wymogi stawiane wobec umowy oraz postanowienia, które jako ius cogens mają zastosowanie w przypadku braku regulacji w umowie. Rząd Kirgistanu zobowiązany został do określenia minimalnych stawek wynagrodzenia za korzystanie z utworów objętych ochroną prawnoautorską oraz za przeniesienie praw autorskich majątkowych (art. 31 ust. 3).

Zapewniono możliwość dochodzenia ochrony praw autorskich na drodze sądowej z możliwością domagania się: uznania praw, przywrócenia stanu sprzed naruszeń, zaprzestania naruszeń, wypłaty odszkodowanie, wydania dochodów uzyskanych w związku z naruszeniem prawa autorskiego, wypłaty kompensaty w kwocie odpowiadającym od 20 do 50 tys. minimalnym wynagrodzeniom. Osoba winna zniszczenia oryginału utworu plastycznego, rękopisu lub ostatecznej wersji utworu audiowizualnego, umyślnie lub w wyniku niedbalstwa, na wniosek twórcy lub uprawnionego z tytułu praw pokrewnych, zobowiązana jest do naprawienia materialnej i moralnej szkody. 


\section{Tadżykistan}

Ochrona prawnoautorska przewidziana w tadżyckiej ustawie została uniezależniona od dopełnienia jakichkolwiek formalności. Przyjęto to rozwiązanie, mimo że jednocześnie przewidziano możliwość zamieszczenie noty copyrightowe (c) na egzemplarzach utworu, informującej o autorstwie oraz o podmiocie posiadającym autorskie prawa majątkowe, a także prawo do dokonania fakultatywnej rejestracji w rejestrze państwowym. Do utworów nieobjętych ochroną ustawową zaliczono: dokumenty urzędowe, znaki i symbole państwowe, proste informacje prasowe o aktualnych wydarzeniach, a także dzieła twórczości ludowej. Za twórców utworów audiowizualnych uznano: reżysera, autora scenariusza, twórcę utworu muzycznego lub słowno-muzycznego powstałego w celu jego wykorzystania w utworze audiowizualnym. W porównaniu z innymi państwami Azji Środkowej, jest najmniejsza grupa osób zaliczanych przez ustawodawców do twórców utworów audiowizualnych.

Dość specyficznie na tle innych państw Azji Środkowej są regulacje odnoszące się do współtwórczości. Zapisano wyraźnie, że nie są współautorami osoby, które udzielały twórcy technicznego, organizacyjnego, finansowego lub innego wsparcia, ponieważ nie stanowi ono twórczości. Jeżeli umowa nie stanowi inaczej, każdy ze współautorów - w myśl ustawy tadżyckiej - jest uprawniony w swoim imieniu, nawet bez uzyskania zgody innych współautorów, do podejmowania działań zmierzających do ochrony praw do utworu. Podejmując je zobowiązany jest jednak poinformować innych współautorów.

Autorskie prawa osobiste do utworów pracowniczych przysługują twórcy, natomiast wyłączne prawo korzystania z utworu pracowniczego - pracodawcy. Jeżeli pracodawca w ciągu trzech lat od skutecznego przekazania utworu pracowniczego nie rozpocznie korzystania z niego - autorskie prawa majątkowe wracają do twórcy.

Do autorskich praw osobistych zaliczono prawo do: autorstwa utworu; oznaczenia go swoim nazwiskiem lub pseudonimem albo udostępniania anonimowo; decydowania o pierwszym udostępnieniu utworu publiczności; nienaruszalności treści i formy utworu oraz jego rzetelnego wykorzystania, a także nadzoru nad sposobem korzystania z utworu. Na autorskie 
prawa majątkowe składają się prawa do: odtwarzania, rozpowszechniania, zezwalania na importowanie egzemplarzy, publiczne odtwarzanie i publiczne wykonanie, nadawania i reemisji, w tym kablowej, tłumaczenia, opracowania, a także opublikowania. Zaznaczono że wyłączne prawo do korzystania $\mathrm{z}$ architektonicznego, urbanistycznego i krajobrazowego utworu zakłada również praktyczną ich realizację. Twórcy takich projektów mają zagwarantowane przez ustawę prawo domagania się od zamawiającego prawa uczestniczenia w realizacji swojego projektu na etapach przygotowywania dokumentacji i budowy, a więc prawo nadzoru nad korzystaniem $\mathrm{z}$ utworu.

Autorskie prawa majątkowe są chronione przez 50 lat po śmierci twórcy lub ostatniego ze współtwórców. Wobec utworu anonimowego stosuje się ochronę w ciągu 50 lat po roku jego rozpowszechnienia. W razie ujawnienia autora, którego utwór został rozpowszechniony anonimowo lub pod pseudonimem, ochrona będzie realizowana - na zasadach ogólnych - 50 lat po śmierci twórcy. Utwory rozpowszechnione w ciągu 30 lat po śmierci twórcy są chronione przez 50 lat, licząc od ich rozpowszechnienia. Zaznaczono że twórca może upoważnić osobę prawną lub fizyczną do ochrony praw do utworu po swojej śmierci. W przypadku niewyznaczenia takiej osoby, prawo to przynależy spadkobiercom ustawowym lub testamentowym. Na uwagę zasługuje fakt, że w przepisie określającym termin i zasady ochrony autorskiego prawa majątkowego zapisano, że autorskie prawo osobiste oraz prawo twórcy do imienia i ochrony reputacji są bezterminowe.

Ustawa tadżycka posługuje się pojęciem domeny publicznej. Zaliczono do niej, poza utworami wobec których prawa autorskie majątkowe wygasły, również utwory, którym nigdy nie udzielono ochrony prawnoautorskiej na terytorium Tadżykistanu. Korzystanie z utworów zaliczonych do domeny publicznej nie jest ograniczone ani pod względem celu, ani podmiotu, ani osiąganych korzyści. Rząd określa opłatę za korzystanie na terenie Tadżykistanu utworów zaliczanych do domeny publicznej. Kwoty te przekazywane są na rzecz specjalnie utworzonych funduszy autorskich oraz organizacjom zbiorowego zarządzania prawa autorskimi. Wysokość tych opłat nie może przekraczać 1 proc. dochodu uzyskanych z tytułu korzystania $\mathrm{z}$ takich utworów. 
Ustawodawca tadżycki przewidział następujące rodzaje dozwolonego użytku: korzystanie z utworów w celach osobistych niekomercyjnych, prawo cytatu w celach naukowych, badawczych, polemicznych, krytycznych $\mathrm{i}$ informacyjnych, przedruk prasowy, korzystanie w celach informacyjnych, w sposób uzasadniony niepełnosprawnością odbiorcy, reprodukcje pojedynczych egzemplarzy przez biblioteki i archiwa. Twórcy zapewniono prawo dostępu do utworu plastycznego nienależącego do twórcy, co nie wiąże się z prawem domagania się dostarczenia tego utworu. Ponadto twórcy przysługuje 5 proc. od ceny sprzedaży profesjonalnej, które należy także jego spadkobiercom w okresie ochrony autorskich praw majątkowych.

Odrębnie uregulowane prawo ochrony wykorzystanego w utworze wizerunku jakiejś osoby. Opublikowanie, odtwarzanie i rozpowszechnianie utworów, w których wykorzystano wizerunek osoby (nie twórcy) możliwe jest pod warunkiem uzyskania jej zgody, a po jej śmierci - zgody spadkobierców, chyba że osoba ta za pozowanie otrzymała zapłatę za pozowanie na podstawie umowy. Szeroko i bardzo szczegółowo opisane zostały warunki zawierania umowy przeniesienia praw autorskich (art. 25-29).

W rozdziale dotyczącym ochrony praw autorskich zajęto się sposobami naruszania oraz dochodzenia ochrony. Do zamkniętej listy form naruszania prawa autorskiego zaliczono: odtworzenie, rozpowszechnienie i inne korzystanie z obiektów prawa autorskiego i prawa pokrewnego bez zgody właściciela autorskiego prawa majątkowego; wytwarzanie i import w celu rozpowszechnienia produkcji lub świadczenie usług, które pozwalają na obejście lub sprzyjają obejściu dowolnych środków technicznych, nakierowanych na ochronę praw autorskich; usunięcie lub zmianę wszelkich informacji o zarządzaniu prawami, bez zgody właściciela autorskich praw majątkowych. Do form ochrony praw autorskich zaliczono instrumenty przewidziane przez kodeks cywilny, a także domaganie się wydania dochodu uzyskanego przez naruszającego prawo autorskie zamiast odszkodowania oraz zapłacenie kompensaty w wysokości określanej przez sąd, zamiast wydania dochodu i odszkodowania. Zapisano ponadto, że materiały i sprzęty wykorzystywane w celu produkcji i odtwarzania nielegalnych egzemplarzy lub fonogramów podlegają zniszczeniu lub przekazaniu na rzecz skarbu państwa. 


\section{Turkmenistan}

Powstanie prawa autorskiego, zgodnie z ustawą turkmeńską, nie jest uzależnione od spełnienia jakichkolwiek formalności i następuje z chwilą powstania utworu. Właściciel autorskich praw majątkowych może poinformować o istnieniu tych praw przez zamieszczenie na egzemplarzu utworu noty copyrightowej $(\odot$ wraz ze wskazaniem osoby lub firmy właściciela praw oraz roku pierwszej publikacji. W ustawie uregulowano w sposób analogiczny do wspólnych postanowień ustaw pozostałych państw Azji Środkowej kwestie współautorstwa, praw do tłumaczeń i opracowania utworów, a także kwestię utworów zbiorowych. Do grona twórców utworów audiowizualnych zaliczono reżysera, twórcę scenariusza oraz autora utworu muzycznego lub słowno-muzycznego stworzonego w celu jego włączenia do utworu audiowizualnego. Wyłączne prawo korzystania z utworu pracowniczego należy do pracodawcy przy jednoczesnym zachowaniu przez twórcę autorskich praw osobistych.

Do autorskich praw osobistych zaliczono prawo do: autorstwa utworu; oznaczenia utworu swoim nazwiskiem lub pseudonimem albo do udostępniania go anonimowo, możliwość decydowania o pierwszym udostępnieniu utworu publiczności oraz o wycofaniu utworu z publicznego dostępu, ochrony reputacji twórcy poprzez ochronę utworu i jego nazwy przez jakimikolwiek ingerencjami, mogącymi naruszyć cześć i godność twórcy. $\mathrm{Na}$ autorskie prawa majątkowe składają się prawa do: odtwarzania, rozpowszechniania, zezwalania na najem egzemplarzy oraz zezwalania importowania egzemplarzy, publicznego odtwarzania i publicznego wykonania; nadawania i reemisji, w tym kablowej, a także tłumaczenia, opracowania i opublikowania. Majątkowe prawa autorskie chronione są przez 50 lat po śmierci twórcy lub ostatniego ze współtwórców. W odniesieniu do utworu anonimowego czas ochrony liczony jest od jego rozpowszechnienia. Majątkowe prawa autorskie utworu opublikowanego po śmierci twórcy trwają przez 50 lat od publikacji.

Twórcy zapewniono dostęp do utworu plastycznego, niebędącego jego własnością, w celu umożliwienia odtworzenia tego utworu, przy jednoczesnym wyłączeniu domagania się dostarczenia utworu twórcy. Ponadto twórca oraz jego spadkobiercy mają prawo do 5 proc. od ceny publicznej 
sprzedaży utworu plastycznego, dokonanej w okresie trwania praw autorskich majątkowych.

Autorskie prawa majątkowe zostały ograniczone przez ustawodawcę do użytku osobistego niekomercyjnego, a także reprograficznego odtworzenia notacji, całych egzemplarzy książek oraz oryginałów utworów plastycznych. Wyłączono jednak możliwość korzystania z utworów architektonicznych, baz danych, programów komputerowych. Za ten rodzaj korzystania przewidziano opłaty należne twórcy, uiszczane poprzez doliczenie do ceny sprzętu oraz nośników, umożliwiających kopiowanie. Wysokość opłat określana jest przez uprawniony przez rząd organ. Umożliwiono korzystanie z utworów, bez zgody twórcy i bez opłaty wynagrodzenia, pod warunkiem wymienienia imienia i nazwiska lub pseudonimu twórcy, na zasadzie cytowania w celach naukowych, badawczych, polemicznych, krytycznych i informacyjnych. Licencją takową objęto również: prawo przedruku prasowego, prawo korzystania, uzasadnionego stopniem i rodzajem niepełnosprawności użytkownika, korzystanie z utworów dla celów postępowania sądowego oraz administracyjnego, podczas oficjalnych państwowych, religijnych i pogrzebowych ceremonii. Przewidziano licencję ustawową dla bibliotek i archiwów, celem odtworzenia zasobów, dokonania reprograficznego sporządzenia kopii utworów rozpowszechnionych w celach naukowych, badawczych oraz dydaktycznych.

Ustawodawca posłużył się pojęciem domeny publicznej. Zaliczono do niej utwory, których autorskie prawa majątkowe wygasły oraz te, które nigdy nie uzyskały ochrony prawnoautorskiej na terenie Turkmenistanu. Korzystanie z utworów znajdujących się w domenie publicznej, pod warunkiem poszanowania autorstwa oraz oznaczenia twórcy, nie jest ograniczone pod względem podmiotu oraz sposobu korzystania.

Ustawodawca turkmeński zdefiniował pojęcie egzemplarza pirackiego, uznając że są nimi wszystkie egzemplarzy wyprodukowane lub rozpowszechniane $\mathrm{z}$ naruszeniem praw autorskich lub pokrewnych, a także egzemplarze importowane bez zgody właściciela praw autorskich lub pokrewnych na terytorium Turkmenistanu z państw, w których ochrona utworów wygasła lub takich, które nigdy nie były nią objęte. Ochrona praw autorskich następuje w formie: uznania prawa, przywrócenia stanu sprzed naruszenia, zaprzestania naruszeń, naprawienia szkody powstałej w wyniku naruszeń, wydania dochodu uzyskanego przez naruszającego w wy- 
niku naruszenia prawa autorskiego lub pokrewnego, wypłaty kompensaty w wysokości określonej przez sąd, w miejsce naprawienia szkody i wydania dochodu. Sąd może orzec konfiskatę i przepadek egzemplarzy pirackich, a także materiałów i sprzętu służących do produkcji pirackich egzemplarzy. Konfiskacie nie podlegają egzemplarze pirackie nabyte przez osoby trzecie w dobrej wierze. Ustawodawca wprowadza pojęcie środków technicznych ochrony praw autorskich rozumiane jako wszelkie technologie, środki techniczne i ich składowe, pozwalające na kontrolę dostępu do utworu, zapobiegające lub ograniczające działania, na które nie wyraził zgody twórca lub właściciel praw autorskich majątkowych.

\section{Podsumowanie}

Analiza ustaw państw Azji Środkowej, leżących niegdyś w granicach b. ZSRR, dowodzi że w gruncie rzeczy odpowiadają one standardom wyznaczonym przez Konwencję berneńską. Przyjęte rozwiązania prawne ustaw prawnoautorskich wywodzą się wyraźnie ze wzorców określonych przez WNP. Mimo podobieństw ustawy różnią się dość poważnie w szczegółach, odzwierciedlając różnice kulturowe i społeczne poszczególnych republik. Z pewnością te odmienności pogłębią stanowiska zarówno judykatury tych państw, jak i administracji rządowych. Problemem może okazać się także doktryna, co do której zaistnienie rozbieżności można przyjąć za praktyczny pewnik. Wszystko to razem wzięte z pewnością utrudni stosowanie ustaw prawnoautorskich na poziomie stosunków między poszczególnymi republikami EaUG, nie wspominając o ewentualnych sporach z obywatelami chociażby państw Unii Europejskiej bądź USA.

\section{DR KSENIA KAKAREKO}

Wydział Dziennikarstwa Informacji i Bibliologii

Uniwersytet Warszawski

ul. Bednarska 2/4, 00-310 Warszawa

ksenia.kakareko@gmail.com 


\section{Bibliografia}

\section{Akty normatywne}

Akt paryski Konwencji berneńskiej o ochronie dzieł literackich i artystycznych z 1971 r., ratyfikowanym dopiero 3 marca 1990 r. Zob. Dz.U. 1990, nr 82, poz. 474.

UNESCO, Universal Copyright Convention and annexed Protocols, „Copyright Bulletin" 2002, T. 26.

Ustawa z dnia 5 marca 1934 r. w sprawie ratyfikacji konwencji berneńskiej o ochronie dzieł literackich i artystycznych z dnia 9 września 1886 r., przejrzanej w Berlinie dnia 13 listopada 1908 r. i w Rzymie dnia 2 czerwca 1928 r., Dz.U. 1934, nr 27, poz. 213.

Ustawa z dnia 13 marca 2003 r. o ratyfikacji Traktatu WIPO o prawie autorskim, sporządzonego w Genewie dnia 1996 r., Dz.U., 2003, nr 80, poz. 715.

Закон СССР от 08.12.1961 Об утверждении основ гражданского законодательства Союза ССР и союзных республик, „Ведомости ВС СССР” 1961, nr 50, poz. $526 \mathrm{z}$ późn. zm.

Закон Республики Казахстан от 10 июня 1996 года № 6-I Об авторском праве и смежных правах, „Ведомости Парламента РК” 1996, nr 8-9, poz. 237, z późn. $\mathrm{zm}$.

Закон Республики Узбекистан N 272-I об авторском праве и смежных правах, „Ведомости Олий Мажлиса Республики Узбекистан” 1996, nr 9, poz. 135.

Закон Кыргызской Республики № 06 от 14.01.1998 г. об авторском праве и смежных правах, „Ведомости Жогорку Кенеша Кыргызской Республики” 1998, nr 3, s. 67.

Закон Республики Таджикистан Об авторском праве и смежных правах, „Ахбори Маджлиси Оли Республики Таджикистан” 1998, nr 23-24, poz. 348.

Закон Республики Узбекистан об авторском праве и смежных правах, „Собрание Законодательства Республики Узбекистан” 2006, nr 28-29, poz. 260.

Закон Туркменистана «Об авторском праве и смежных правах», „Ведомости Меджлиса Туркменистана” 2012, nr 1, poz. 8.

Закон Туркменистана № 256-IV O внесении изменений и дополнений в Гражданский кодекс Туркменистана, „Ведомости Меджлиса Туркменистана” 2012, nr 1, poz. 1007.

Постановление Верховного Совета СССР О введении в действие Основ гражданского законодательства Союза ССР и республик, „Ведомости Съезда народных депутатов СССР и Верховного Совета СССР” 1991, nr 26, poz. 734.

Постановление Межпарламентской Ассамблеи государств - участников Содружества Независимых Государств от 18 ноября 2005 г. № 26-13 «О новой редакции модельного закона «Об авторском праве и смежных правах» „Информационный бюллетень Межпарламентской Ассамблеи СНГ” 2006, nr 37.

Постановление Межпарламентской Ассамблеи Евразийского экономического сообщества от 16 мая 2012 г. № 14-16 «О Рекомендациях по гармонизации 
законодательства государств - членов ЕврАзЭС в области авторского права и смежных прав (на основе сравнительно-правового анализа национальных законодательств)», niepubl.

Постановление Правительства Республики Казахстан № 1083 от 20.10.2004 г. «Об утверждении минимальных ставок авторского вознаграждения за некоторые виды использования произведений».

Соглашение О Сотрудничестве В Области Охраны Авторского Права И Смежных Прав, nr w WIPO Lex TRT/APCNR/001, http://www.wipo.int/wipolex/ru/ other_treaties/text.jsp?file_id=215032 [dostęp 10.03.2018].

Соглашение от 20 ноября 2009 года о сотрудничестве по организации межгосударственного обмена информацией и формированию национальных баз данных авторского права и смежных прав, http://www.wipo.int/edocs/lexdocs/ treaties/ru/ciseicr/trt_ciseicr_001ru.pdf [dostęp 10.03.2018].

\section{Literatura}

Elst, M. (2005). Copyright, Freedom of Speech, and Cultural Policy in the Russian Federation, Leiden-Boston: Brill-Nijhoff.

Goldman, W.S. (1990. Berne-ing the Soviet Copyright Codes: Will the U.S.S.R. Alter Its Copyright Laws to Comply with the Berne Convention, Dickinson Journal of International Law, 8(395).

Date of accession by the Soviet Union, continued by the Russian Federation as from December 25, 1991. Pobrane z: https://web.archive.org/web/20071030123939/ http://www.wipo.int/treaties/en/Remarks.jsp?cnty_id=1238C [dostęp 10.03.2018]. Kakareko, K. (2017). Prawa pokrewne wydawców czasopism naukowych, Acta Iuris Stetinensis (Roczniki Prawnicze), 2(18), 115-134.

Sobczak, J., Kakareko, K. (2017). Czy istnieje potrzeba wyodrębnienia praw pokrewnych wydawców? W: J. Mianowski (red.), Stowarzyszenie prasy lokalnej. Od 25 lat buduje społeczeństwo obywatelskie (34-43). Poznań: Wągrowiecka Oficyna Wydawnicza Sp. z o.o. 